\title{
Trends in Precipitation, Runoff, and Evapotranspiration for Rivers Draining to the Gulf of Maine in the United States*
}

\author{
T. G. Huntington \\ United States Geological Survey, Augusta, Maine \\ M. BILLMIRE \\ Michigan Tech Research Institute, Michigan Technological University, Ann Arbor, Michigan
}

(Manuscript received 23 January 2013, in final form 19 November 2013)

\begin{abstract}
Climate warming is projected to result in increases in total annual precipitation in northeastern North America. The response of runoff to increases in precipitation is likely to be more complex because increasing evapotranspiration (ET) could counteract increasing precipitation. This study was conducted to examine these competing trends in the historical record for 22 rivers having $>70 \mathrm{yr}$ of runoff data. Annual (water year) average precipitation increased in all basins, with increases ranging from 0.9 to $3.12 \mathrm{~mm} \mathrm{yr}^{-1}$. Runoff increased in all basins with increases ranging from 0.67 to $2.58 \mathrm{~mm} \mathrm{yr}^{-1}$. The ET was calculated by using a water balance approach in which changes in terrestrial water storage were considered negligible. ET increased in 16 basins and decreased in 6 basins. Temporal trends in temperature, precipitation, runoff, and ET were also calculated for each basin over their respective periods of record for runoff and for the consistent period (19272011) for the area-weighted average of the nine largest non-nested basins. From 1927 through 2011, precipitation and runoff increased at average rates of 1.6 and $1.7 \mathrm{~mm} \mathrm{yr}^{-1}$, respectively, and ET increased slightly at a rate of $0.18 \mathrm{~mm} \mathrm{yr}^{-1}$. For the more recent period (1970-2011), there was a positive trend in ET of $1.9 \mathrm{~mm} \mathrm{yr}^{-1}$. The lack of a more consistent increase in ET, compared with the increases in precipitation and runoff, for the full periods of record, was unexpected, but may be explained by various factors including decreasing wind speed, increasing cloudiness, decreasing vapor pressure deficit, and patterns of forest growth.
\end{abstract}

\section{Introduction}

Emerging evidence indicates that climate warming is affecting the global hydrologic cycle by increasing rates of evaporation, transpiration, and precipitation, and by increasing atmospheric water vapor content (Huntington 2010; Rawlins et al. 2010; Syed et al. 2010; Wentz et al. 2007) and increasing variance of extreme precipitation events (Trenberth 2011; Tebaldi et al. 2006). These changes in the hydrologic cycle are consistent with theory and predictions of climate responses to warming (Trenberth 1999; Held and Soden 2000, 2006). In spite of overall global trends, specific regions have experienced

\footnotetext{
* Supplemental information related to this paper is available at the Journals Online website.

Corresponding author address: T. G. Huntington, U.S. Geological Survey, 196 Whitten Rd., Augusta, ME 04330.

E-mail: thunting@usgs.gov
}

distinctly different hydrologic responses with wet areas generally becoming wetter and dry areas becoming drier (Bates et al. 2008; Trenberth 2011).

In North America (Walter et al. 2004), most of Europe (Teuling et al. 2009), and southeastern South America (Garcia and Mechoso 2005), precipitation and runoff increased over large river basins during the twentieth century. In these studies precipitation increased more than runoff, indicating that evapotranspiration (ET) had increased. A recent global analysis of modeled runoff indicated that starting in about 1980 , increases in runoff failed to keep pace with increases in precipitation, which indicated that increases in temperature contributed to an increase in ET at the expense of runoff (McCabe and Wolock 2011a). In another analysis, Jung et al. (2010) reported that ET increased from 1982 through 1997, but that the increase seemed to have ceased between 1998 and 2008, which they interpreted as due to a limited moisture supply. Douville et al. (2013) reported generally 
increasing ET for latitudes $>30^{\circ} \mathrm{N}$ from 1950 to 2005 reaching a peak in 1998 and slightly declining through 2005 , coincident with trends in air temperature. A recent analysis in the northeastern United States reported trends toward increasing precipitation, runoff, and water table elevation during recent decades that were more pronounced in the last 10 years (Weider and Boutt 2010, hereafter WB2010).

Regional responses to ongoing climate change are not well characterized but are important for water resource management and planning and adaptation to further changes in hydrologic conditions. Evaporation and transpiration are the most challenging hydrologic variables to estimate because they cannot be measured directly in natural settings (apart from within small plots) and because there are large uncertainties associated with indirect atmospheric modeling and satellite-derived products used to estimate ET (Gao et al. 2010; Ferguson et al. 2010; Sheffield et al. 2010; Vinukollu et al. 2011). River basin water-balance studies can be useful for the purpose of indirectly estimating ET and for calibration of land surface models for processes such as ET (Senay et al. 2011).

The quantity ET can be inferred as the residual [precipitation (PPT) - runoff $(R)$ ] where, over sufficiently long time periods, the assumptions of no appreciable change in terrestrial water storage and that all groundwater outputs are captured in measured runoff are accurate. This method has been applied to determine trends in major rivers in the United States (Milly and Dunne 2001; Qian et al. 2007; Walter et al. 2004) and in South America (Berbery and Barros 2002) but has not been applied to river basins draining to the Gulf of Maine.

Climate projections for the northeastern United States generally indicate increasing precipitation in winter, and to a lesser extent in spring and fall, but no change or only small increases in summertime precipitation (Hayhoe et al. 2007; Karl et al. 2009; Seager et al. 2013). Increases in summertime temperatures and ET are expected to result in a decrease in soil moisture content across the region (Hayhoe et al. 2007; Anderson et al. 2010). Climate projections also suggest that the observed lengthening of the growing season in the northeastern United States during the twentieth century (Wolfe et al. 2005; Schwartz et al. 2006; Dragoni and Rahman 2012) is likely to continue and accelerate in the twenty-first century (Hayhoe et al. 2007; Morin et al. 2009). We tested the hypotheses that the historical record would show increasing temperature, precipitation, runoff, and ET in river basins in the Gulf of Maine watershed. We also tested the hypotheses that observed changes in precipitation would be correlated with changes in temperature and that changes in ET over time could be related to changes in air temperature and land cover.

\section{Description of the study area}

All river basins in the United States draining to the Gulf of Maine (GoM) having $>70 \mathrm{yr}$ continuous streamflow record through 2010 were included in this analysis. Twenty basins met this criterion and two additional basins with partial records were included because standard record extension techniques could be used to obtain $>70 \mathrm{yr}$ of record (Table 1 ). In some cases smaller rivers are nested within larger river basins as indicated in Fig. 1. The basins ranged in size from 190 to $17000 \mathrm{~km}^{2}$. For river basins that were not nested within other basins (Fig. 1) the aggregate area is about $68000 \mathrm{~km}^{2}$ (38\% of the drainage area of the GoM). The St. John River is the largest river flowing into the GoM, draining an area of about $55000 \mathrm{~km}^{2}$, but this analysis included only the upper reaches that are in the United States $\left(14700 \mathrm{~km}^{2}\right)$. The Penobscot River is the second largest river in New England, draining an area of $17278 \mathrm{~km}^{2}$ at the gage in West Enfield, Maine. The length of discharge records varied from 71 to $109 \mathrm{yr}$ (median $83 \mathrm{yr}$ ).

The climate of the study area is humid continental (Peel et al. 2007) and precipitation ranges from about $0.9 \mathrm{~m} \mathrm{yr}^{-1}$ in the north to as much as $1.20 \mathrm{~m} \mathrm{yr}^{-1}$ in coastal sections (http://www.prismclimate.org). Precipitation is relatively evenly distributed seasonally and annual snowfall ranges from about $1.5 \mathrm{~m}$ in southern and coastal areas to $>2 \mathrm{~m}$ in inland areas (Cember and Wilks 1993). The typical seasonal pattern of streamflow shows a distinct spring peak during snowmelt, with lowest flows during late summer and early fall (Hodgkins and Dudley 2005). Runoff ranges from $55 \%$ to $65 \%$ of rainfall inputs (Randall and Cohen 1998).

The physiography of the region is characterized by hilly to mountainous plateau terrain in western sections and hills and lowlands in the central and southeastern coastal region (Toppan 1935). Maine watersheds are primarily comprised of forest land $(\sim 89 \%)$ (Griffith and Alerich 1996). Of the remaining land coverage, $5 \%$ is covered by $\sim 5700$ lakes, swamps, and ponds $>0.4$ ha, and $4 \%$ is in agriculture. Palustrine wetlands occupy $\sim 12 \%$ of the land area in Maine; $60 \%$ of these wetlands are forested and the remainder are scrub/shrub or emergent vegetation (Armstrong 1996). The Merrimack River Basin is largely in New Hampshire and consists of $67 \%$ forest land; urban land, agricultural land, and open water cover $13 \%, 5 \%$, and $4 \%$ of the basin respectively; $4.5 \%$ of the land is covered by forested wetlands and $1 \%$ is covered by emergent herbaceous wetlands (Falcone et al. 2010). 


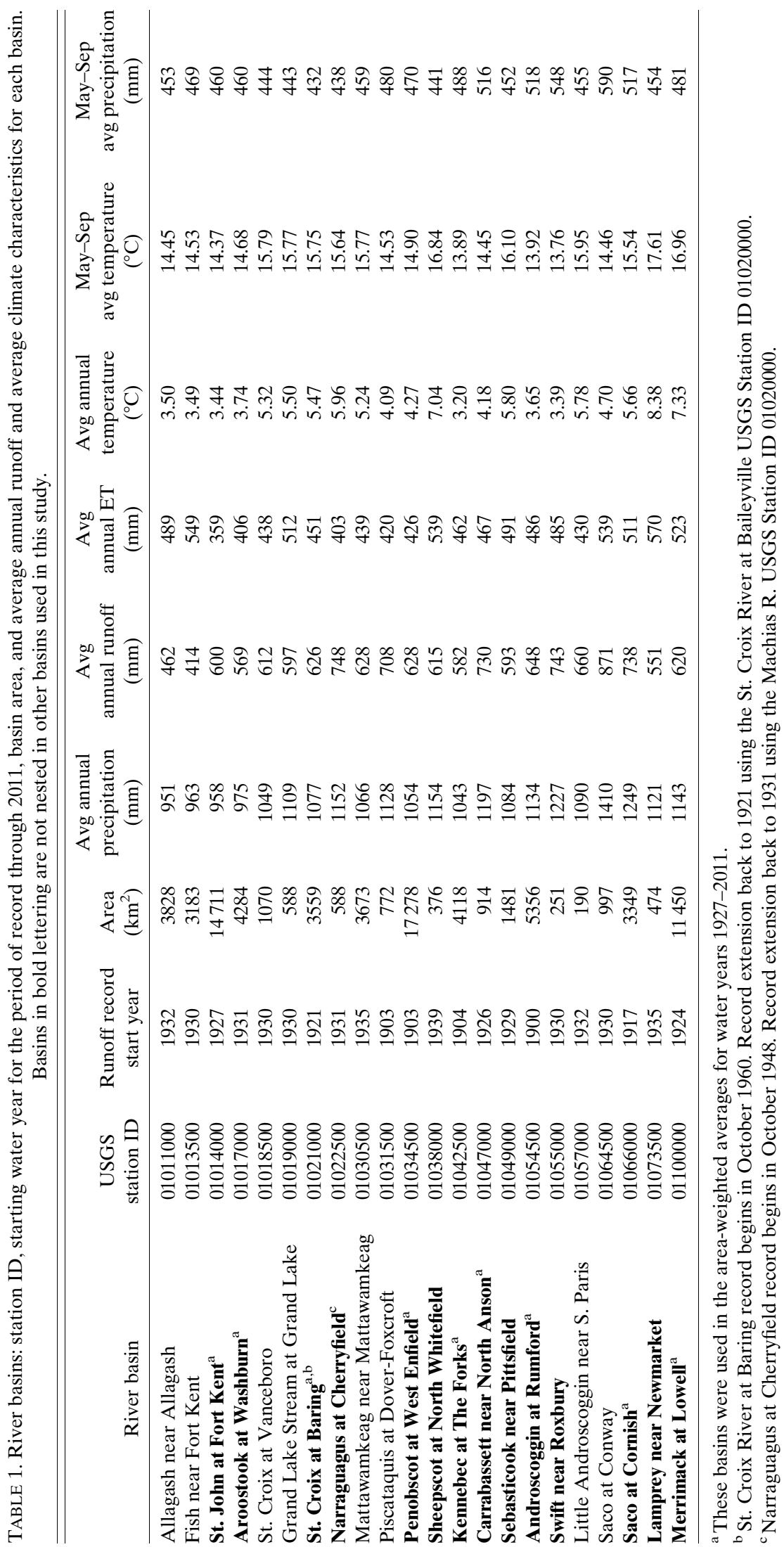




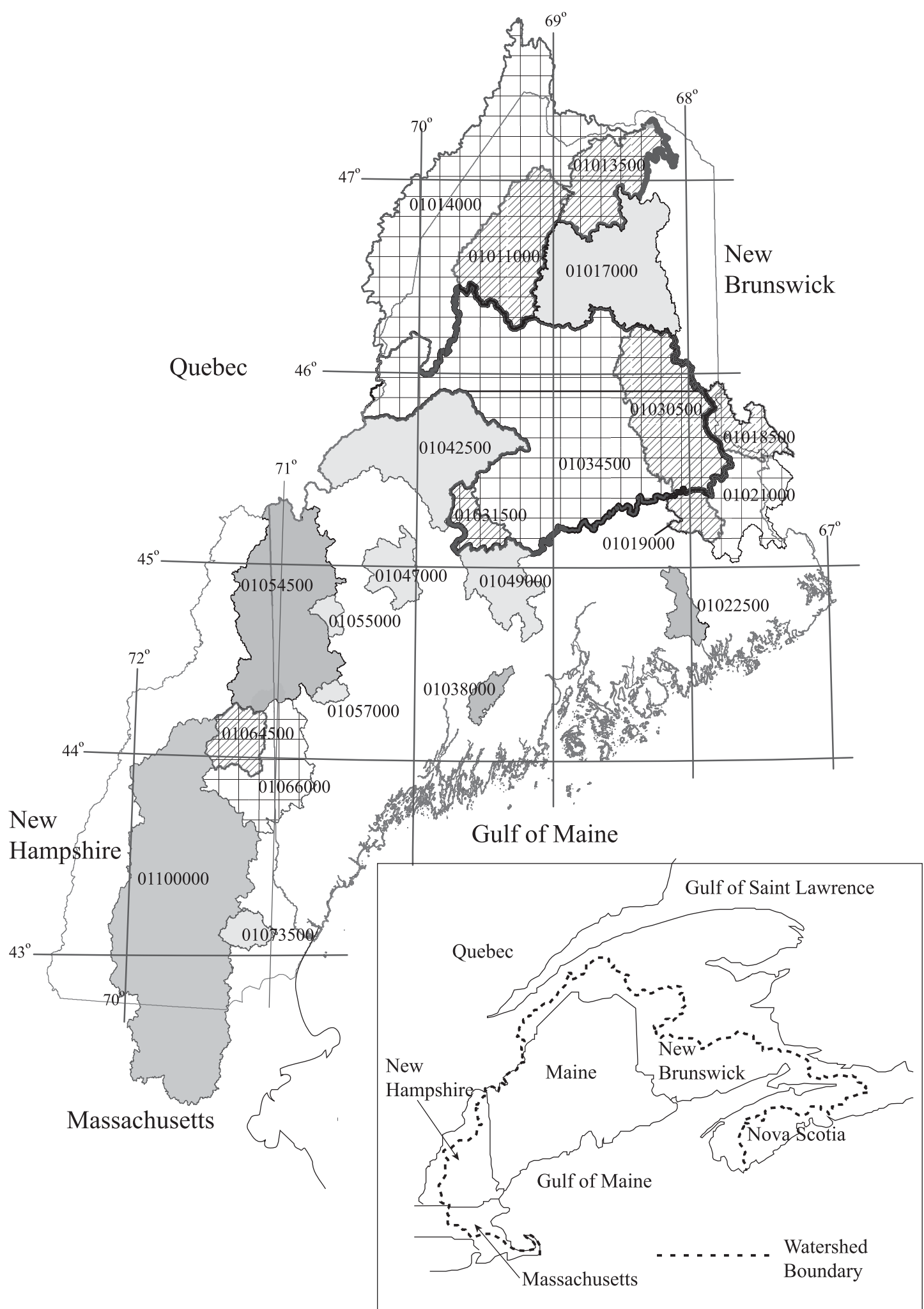

FIG. 1. River basins in the study with numbers identifying the USGS stations where these basins are gauged (see Table 1). Basins shown with diagonal lines are nested within the larger basins shown with rectangular grids. Basins 01011000 and 01013500 are nested within 01014000. Basins 01030500 and 01031500 are nested within 01034500 . Basins 01018500 and 01019000 are nested within 01021000 . Basin 01064500 is nested within basin 01066000 . The inset shows the Gulf of Maine (GoM) watershed. 


\section{Methods}

Monthly average streamflow data for each river (Table 1) were obtained from the National Water Information System (NWIS) online database (http://nwis.waterdata. usgs.gov/nwis/sw). The accuracy of daily discharge records varies by site in this study area (Stewart et al. 2006 ), but usually is rated good ( $\geq 95 \%$ of the daily record is within $10 \%$ of the true value) except under ice when they are rated poor where the accuracy is less than fair ( $\geq 95 \%$ of the daily record is within $15 \%$ of the true value). There is no evidence that errors in discharge measurement are biased in sign or temporally biased. Where record extension techniques were used to estimate discharge (noted below) the uncertainty in discharge measurements increased and there is a potential for bias that we cannot quantify.

For the St. Croix River at Baring, Maine, (01021000) and Narraguagus River at Cherryfield, Maine, (01022500) in southeastern Maine, streamflow records were available for part of the study period. Standard record extension techniques were used to estimate flow during periods when the rivers were not gauged. For the St. Croix River at Baring, a simple area adjustment (Hodgkins 1999) based on discharge for the St. Croix at Baileyille (01020000) with individual monthly regressions developed from the overlapping record (1960-83) was used for record extension. The Maintenance of Variance Extension, type 1 (MOVE.1) line of organic correlation regression model (Hirsch 1982) was used for the Narraguagus River with the overlapping record (194877 and 2001-09) from the nearby Machias River at Whitneyville (01021500).

All basins were included in time series analyses extending over the period of record for discharge for each individual basin (Table 1). The annual time period was based on water years (1 October through 30 September; for example, water year 1927 begins on 1 October 1926). In a separate analysis, only data from the nine largest non-nested basins were included (Table 1). These nine basins have an aggregate area of $65019 \mathrm{~km}^{2}$. In this case, we computed area-weighted average annual values for precipitation, runoff, ET, and air temperature. This analysis was conducted for the consistent time period 1927 through 2011. The Aroostook River did not have data for 1927 through 1930; for these years the areaweighted averages were computed from the other eight basins having an aggregate area of $60735 \mathrm{~km}^{2}$.

Monthly gridded precipitation and surface air temperature data were obtained from the ParameterElevation Regressions on Independent Slopes Model (PRISM) database, spatial resolution 0.04167 decimal degrees latitude and longitude (approximately 4-km grid cells) (http://www.prism.oregonstate.edu; Daly et al. 2008). These datasets incorporate station observations with a digital elevation model, proximity to coasts, knowledge of orographic effects, and expert knowledge of complex climatic extremes (Daly et al. 2002, 2008). PRISM data are recognized as one of the highest quality and most sophisticated spatial climate datasets (Cheng et al. 2011). The PRISM data are based on station data, the large majority of which are from the National Weather Service Cooperative Observer Program (COOP) (Daly et al. 2008). The station data have not been adjusted for all known biases, as the much smaller set of U.S. Historical Climate Network (USHCN) station data has (Williams et al. 2005), and therefore caution is necessary when PRISM data are used for time series analysis. One way to evaluate the PRISM data is to compare trends derived with PRISM and with the bias-corrected USHCN data (McCabe and Wolock 2011b). We compared longterm trends (1920-2011) in total annual precipitation derived from the $25 \mathrm{USHCN}$ stations in or adjacent to our study area with trends derived from the PRISM grid cells that those USHCN stations were located in. The trends using USHCN data averaged $2.27( \pm 0.22 \mathrm{SE}) \mathrm{mm} \mathrm{yr}^{-1}$ and the trends using PRISM data averaged $2.02( \pm 0.17$ SE) $\mathrm{mm} \mathrm{yr}^{-1}$. The correlation between the annual precipitation estimated from PRISM and estimated from the USHCN stations was $r=0.99$. We compared long-term trends (1920-2010) in average annual temperature derived from the 25 USHCN stations in or adjacent to our study area with trends derived from the PRISM grid cells that those USHCN stations were located in. The trends using USHCN data averaged $0.0122( \pm 0.00072$ $\mathrm{SE})^{\circ} \mathrm{Cyr}^{-1}$ and the trends using PRISM data averaged $0.0115( \pm 0.00074 \mathrm{SE})^{\circ} \mathrm{C} \mathrm{yr}^{-1}$. Given the correlation and similar trends, the PRISM data appear to be suitable for time series analysis in this region for this time period.

Monthly gridded temperature and precipitation data were incorporated in a Geographic Information System (GIS) database that included the watershed basin boundaries [GAGES2 (Falcone et al. 2010) and U.S Geological Survey (USGS) digital files from the Maine Water Science Center]. Using ARCMap 10.1 tools monthly precipitation and temperature were computed for each basin extracted from the gridded data. Data for runoff and precipitation for each basin were summarized on an annual basis. Monthly North Atlantic Oscillation data were obtained from the National Oceanic and Atmospheric Administration (NOAA) web site (http://www.cpc. ncep.noaa.gov/products/precip/CWlink/pna/nao.shtml).

To estimate ET for this study we used the water balance approach where the difference between precipitation $(P)$ and runoff $(\mathrm{Ru})$ can be described by the following equation (Scanlon et al. 2002; Healy et al. 2007): 


$$
P-\mathrm{Ru}=\mathrm{ET}+\frac{d S}{d t}(\mathrm{sw})+\frac{d S}{d t}(\mathrm{uz})+\frac{d S}{d t}(\mathrm{gw}),
$$

where $P-\mathrm{Ru}$ is partitioned into ET, change in surface water storage $d S / d t(\mathrm{sw})$, change in moisture storage in the unsaturated zone $d S / d t(\mathrm{uz})$, and change in storage of groundwater $d S / d t(\mathrm{gw})$. Over sufficiently long time periods (e.g., decades), the changes in terrestrial water storage (TWS) in rivers and lakes, soil, and aquifers are small compared with changes in precipitation and runoff amounts and can be considered negligible (Domokos and Sass 1990; Gao et al. 2010; Senay et al. 2011). We expect that negligible TWS is especially true in the Gulf of Maine watershed where annual precipitation is generally $>1000 \mathrm{~mm}$ and is evenly distributed throughout the year, where there are few large reservoirs and aquifer storage is low. The great majority of the land surface is underlain by a shallow glacial till over bedrock rather than sand and gravel (Kontis et al. 2004, plate C). In Maine sand and gravel aquifers are particularly scarce. The area-weighted average sand and gravel abundance on 26 river basins in Maine was 4.16\% (Dudley 2004) and this estimate is biased high because a disproportionate number of these basins were in southeastern Maine where the abundance of sand and gravel aquifers is highest (Dudley 2004). For these reasons, we assumed that changes in TWS were negligible.

Growing season average temperature and average precipitation were computed as the average of the months of May through September, which best approximates with the period when actively transpiring leaves are on deciduous trees in Maine. Growing degree days (GDD) data were obtained from the Northeast Regional Climate Center, Ithaca, New York, in October 2010 (J. Rennels 2011, personal communication) for NOAA's National Climatic Data Center (NCDC) cooperative stations having at least $40 \mathrm{yr}$ of record. Eleven out of the 15 stations used in this analysis were USHCN stations where the data have been corrected for all known biases. Two of the four other stations are National Weather Service "First-Order Stations." The locations of the stations can be accessed online (at http:// www.ncdc.noaa.gov/land-based-station-data/stationmetadata/surface-station-listings). There were fewer stations in higher elevations in Maine near the New Hampshire border than in the rest of Maine. GDD over the northeast region are calculated by using a different time period (April-October) than we used for growingseason temperature and precipitation. The calculation of annual sums of GDD used a base of $50^{\circ} \mathrm{F}$ and results in a cumulative sum of the daily mean temperature in Fahrenheit minus 50 for each day during the period. We calculated the Sen slopes (Salmi et al. 2002) for the time series of annual GDD sums for each of the stations. Missing values in the temperature data used in the calculation of growing degree days (base $50^{\circ} \mathrm{F}$ ) were estimated by interpolation between adjacent days when there were fewer than 3 days missing. If there were more than two consecutive days of missing data in a given year that year was excluded from the analysis. Missing data were rare for Farmington and Millinocket and did not occur for Portland.

Mann-Kendall nonparametric trend tests for testing for the presence of monotonic increasing or decreasing trends in temperature, precipitation, runoff, and ET were determined by using SPlus 8.1 software. The Durbin-Watson " $d$ statistic" was calculated for each time series to test for the presence of positive or negative serial correlation (Durbin and Watson 1971). We tested the runoff, precipitation, ET, and air temperature time series for each of the 22 river basins and for the areaweighted average time series for 1927 to 2011 . We found no evidence for positive or negative serial correlation for any of these time series (see Table S1, available as supplemental material at the Journals Online website: http://dx.doi.org/10.1175/JHM-D-13-018.s1). The nonparametric Sen's method for estimating the slope of a linear trend was selected by using MAKESENS software (Salmi et al. 2002). The data were smoothed for graphical presentation by use of the nonparametric locally-weighted scatterplot smoothing (LOESS) regression (Cleveland and Devlin 1988). Correlation analyses between climate variables and between ET and land cover variables were performed with S-Plus 8.1 software using the nonparametric Kendall tau statistic. Kendall's tau rank coefficient is a statistic used to measure the relationship between two variables. The statistical test is a nonparametric hypothesis and does not require that the data conform to a normal distribution. For this analysis $p$ values of $<0.05$ were considered statistically significant.

For the average annual net-growth of growing-stock trees, Forest Inventory Analysis (FIA) data for 2006 and 2010 data [ $\geq 5$ inches d.b.h (tree diameter at breast height)] were downloaded (from http://apps.fs.fed.us/ fiadb-downloads/standardReports.html). Earlier FIA inventories were obtained from K. Laustsen (Maine State Forest Service, 2006, personal communication) and Gadzik et al. (1998). This data type refers to merchantable timber and includes all ownership classes of timberland.

Watershed characteristic data were obtained from the GAGESII database (Falcone et al. 2010). Data were obtained for 19 of the 22 basins studied. The three basins not included (St. John River at Fort Kent and the St. Croix River at Baring and Vanceboro) contain 
TABLE 2. Trends (nonparametric Sen slopes) in annual and seasonal surface air temperature (PRISM data) corresponding to the period of record for runoff record (starting water year is shown) through 2011. Also shown are the significance levels obtained with the MannKendall trend test. Degrees per century are given as ${ }^{\circ} \mathrm{C}(100 \mathrm{yr})^{-1}$. Significance levels (Sig) for tests for Sen slopes $\neq 0(p$ values for: $* * *=<0.001, * *=<0.01, *=<0.05,+=<0.1$, blank $=>0.1)$.

\begin{tabular}{|c|c|c|c|c|c|c|c|}
\hline \multirow[b]{2}{*}{ Basin } & \multirow[b]{2}{*}{ Station ID } & \multirow[b]{2}{*}{ Start year } & \multirow[b]{2}{*}{ Area $\left(\mathrm{km}^{2}\right)$} & \multicolumn{2}{|c|}{$\begin{array}{l}\text { Annual avg } \\
\text { temperature }\end{array}$} & \multicolumn{2}{|c|}{$\begin{array}{l}\text { May-Sep avg } \\
\text { temperature }\end{array}$} \\
\hline & & & & $\begin{array}{c}\text { Trend } \\
{\left[{ }^{\circ} \mathrm{C}(100 \mathrm{yr})^{-1}\right]}\end{array}$ & Sig & $\begin{array}{c}\text { Trend } \\
{\left[{ }^{\circ} \mathrm{C}(100 \mathrm{yr})^{-1}\right]}\end{array}$ & Sig \\
\hline Allagash near Allagash & 01011000 & 1932 & 3828 & -0.30 & & -0.290 & \\
\hline Fish near Fort Kent & 01013500 & 1930 & 3183 & 0.20 & & 0.280 & \\
\hline St. John at Fort Kent & 01014000 & 1927 & 14711 & 0.00 & & -0.001 & \\
\hline Aroostook at Washburn & 01017000 & 1931 & 4284 & 0.10 & & 0.110 & \\
\hline St. Croix at Vanceboro & 01018500 & 1930 & 1070 & 0.50 & & 0.300 & \\
\hline Grand Lake Stream at Grand Lake & 01019000 & 1929 & 588 & 0.70 & $*$ & 0.400 & + \\
\hline St. Croix at Baring & 01021000 & 1920 & 3559 & 1.00 & $* * *$ & 0.740 & $* * *$ \\
\hline Narraguagus at Cherryfield & 01022500 & 1930 & 588 & 0.80 & $*$ & 0.543 & \\
\hline Mattawamkeag near Mattawamkeag & 01030500 & 1935 & 3673 & 0.10 & & -0.14 & \\
\hline Piscataquis at Dover-Foxcroft & 01031500 & 1903 & 772 & 0.80 & $* *$ & 0.458 & $*$ \\
\hline Penobscot at West Enfield & 01034500 & 1903 & 17278 & 0.60 & $* *$ & 0.495 & $* *$ \\
\hline Sheepscot at North Whitefield & 01038000 & 1939 & 376 & 0.30 & & 0.185 & \\
\hline Kennebec at The Forks & 01042500 & 1904 & 4118 & 0.90 & $* * *$ & 0.554 & $* *$ \\
\hline Carrabassett near North Anson & 01047000 & 1926 & 914 & 0.60 & $*$ & 0.328 & \\
\hline Sebasticook near Pittsfield & 01049000 & 1929 & 1481 & -0.20 & & -0.206 & \\
\hline Androscoggin at Rumford & 01054500 & 1900 & 5356 & 1.30 & $* * *$ & 0.960 & $* * *$ \\
\hline Swift near Roxbury & 01055000 & 1930 & 251 & 1.90 & $* * *$ & 1.109 & $* * *$ \\
\hline Little Androscoggin near S. Paris & 01057000 & $1914^{\mathrm{a}}$ & 190 & 1.00 & $* * *$ & 0.617 & $*$ \\
\hline Saco at Conway, NH & 01064500 & 1930 & 997 & 0.50 & & 0.393 & \\
\hline Saco at Cornish & 01066000 & 1917 & 3349 & 0.90 & $* *$ & 0.704 & $* *$ \\
\hline Lamprey near Newmarket, NH & 01073500 & 1935 & 474 & 0.40 & & 0.410 & \\
\hline Merrimack at Lowell, MA & 01100000 & 1924 & 11450 & 0.50 & + & 0.539 & $*$ \\
\hline
\end{tabular}

${ }^{\mathrm{a}}$ Missing record for 1924 through 1932.

drainage area that is in Canada. The GAGESII database does not include areas in Canada. The GAGESII database provides watershed average percent forest cover (by forest type), percent wetland (by wetland type), and percent agriculture, pasture, grassland, and open water. In addition, various soil characteristic values were also obtained including water infiltration, drainage properties, organic matter content, texture, bulk density, and soil thickness.

\section{Results}

\section{a. Average annual temperature, precipitation, runoff, and ET in all basins}

Average annual temperature within river basins varied from $3.2^{\circ}$ to $8.4^{\circ} \mathrm{C}$ and growing season temperature varied from $13.8^{\circ}$ to $17.6^{\circ} \mathrm{C}$ throughout the study area. Temperatures decreased from south to north and from east to west, the latter associated with the proximity to the coast (east) or mountainous areas (west) (Table 1). Average annual basin precipitation (for non-nested basins) for the periods of record corresponding to the discharge records varied from 958 to $1250 \mathrm{~mm}$ (area-weighted average $1060 \mathrm{~mm}$ ) and tended to decrease from south to north (Table 1). Precipitation was distributed fairly evenly throughout the year. Growing season (MaySeptember) precipitation varied from 430 to $548 \mathrm{~mm}$ (area-weighted average $465 \mathrm{~mm}$; Table 1). Average annual basin runoff for non-nested basins varied from 551 to $748 \mathrm{~mm}$ (median $622 \mathrm{~mm}$ ). Average annual basin ET for non-nested basins (calculated as $P-R$, where $R$ is runoff) varied from 359 to 570 (area-weighted average $443 \mathrm{~mm})$.

\section{b. Temporal trends in temperature, precipitation, runoff, and ET in all basins}

Average annual temperature for the period of runoff record increased in 20 out of 22 basins-the increases were statistically significant $(p<0.05)$ in 11 basins and marginally significant $(p<0.1)$ in one basin (Table 2$)$. The basins with significant increases tended to be those with the longest record length. Increases in minimum temperature were nearly twice as large as increases in maximum temperatures (data not shown). The trends in the basins showing decreasing average annual temperature were not statistically significant. Average temperatures 
TABLE 3. Trends in annual precipitation, runoff and evapotranspiration for the period of record through 2011. (PPT $=$ precipitation, $\mathrm{GS}=$ growing season, $R=$ runoff). Also shown are the significance levels obtained with the Mann-Kendall trend test. Significance levels for tests for Sen slopes $\neq 0$ ( $p$ values for: $* * *=<0.001, * *=<0.01, *=<0.05,+=<0.1$, blank $=>0.1)$.

\begin{tabular}{|c|c|c|c|c|c|c|c|c|c|c|}
\hline \multirow[b]{2}{*}{ Basin } & \multirow[b]{2}{*}{ Area $\left(\mathrm{km}^{2}\right)$} & \multicolumn{2}{|c|}{$\begin{array}{l}\text { Nonparametric } \\
\text { PPT Sen slope }\end{array}$} & \multirow{2}{*}{$\begin{array}{l}\text { GS PPT } \\
\text { slope } \\
\left(\mathrm{mm} \mathrm{yr}^{-1}\right)\end{array}$} & \multirow[b]{2}{*}{ Sig } & \multirow{2}{*}{$\begin{array}{c}\text { Sen } \\
\frac{R}{\text { \% increase }}\end{array}$} & \multicolumn{2}{|c|}{$\begin{array}{l}\text { Nonparametric } \\
R \text { Sen slope }\end{array}$} & \multicolumn{2}{|c|}{$\begin{array}{c}\text { Nonparametric } \\
\text { PPT }-R(\mathrm{ET}) \\
\text { Sen slope }\end{array}$} \\
\hline & & $\mathrm{mm} \mathrm{yr}^{-1}$ & Sig & & & & $\mathrm{mm} \mathrm{yr}^{-1}$ & Sig & $\mathrm{mm} \mathrm{yr}^{-1}$ & Sig \\
\hline Allagash & 3828 & 1.67 & $*$ & 0.76 & $*$ & 11.5 & 0.67 & & 0.95 & $* *$ \\
\hline Fish near Fort Kent & 3183 & 1.70 & $*$ & 0.60 & + & 20.0 & 1.02 & $*$ & 0.67 & + \\
\hline St. John at Fort Kent & 14711 & 1.58 & $*$ & 0.64 & $*$ & 10.8 & 0.77 & & 0.67 & $*$ \\
\hline Aroostook at Washburn & 4284 & 1.69 & $*$ & 0.56 & & 19.0 & 1.35 & $*$ & 0.25 & \\
\hline St. Croix at Vanceboro & 1070 & 2.05 & $* *$ & 0.53 & & 20.8 & 1.57 & + & 0.69 & \\
\hline Grand Lake Stream at Grand Lake & 588 & 2.61 & $* *$ & 0.82 & + & 15.2 & 1.12 & & 1.49 & $*$ \\
\hline St. Croix at Baring & 3559 & 2.83 & $* * *$ & 0.76 & $*$ & 23.4 & 1.63 & $*$ & 1.06 & $*$ \\
\hline Narraguagus at Cherryfield & 588 & 2.35 & $* *$ & 0.70 & & 17.3 & 1.62 & + & 0.66 & \\
\hline Mattawamkeag nr. Mattawamkeag & 3673 & 2.38 & $*$ & 0.91 & $*$ & 23.0 & 1.90 & $* *$ & 0.32 & \\
\hline Piscatgaquis at Dover-Foxcroft & 772 & 1.35 & $* *$ & 0.32 & & 13.9 & 0.91 & + & 0.37 & \\
\hline Penobscot at West Enfield & 17278 & 1.53 & $* *$ & 0.56 & $*$ & 18.2 & 1.06 & $*$ & 0.46 & + \\
\hline Sheepscot at North Whitefield & 376 & 2.49 & $*$ & 1.64 & $* *$ & 30.2 & 2.58 & $* *$ & -0.15 & \\
\hline Kennebec at The Forks & 4118 & 1.51 & $* *$ & 0.41 & & 23.0 & 1.25 & $* *$ & 0.27 & \\
\hline Carrabasset near North Anson & 914 & 1.02 & & 0.69 & & 27.9 & 2.40 & $* *$ & -1.21 & $* *$ \\
\hline Sebasticook near Pittsfield & 1481 & 1.75 & $*$ & 0.93 & $*$ & 19.9 & 1.44 & + & 0.31 & \\
\hline Androscoggin at Rumford & 5356 & 0.91 & $*$ & 0.27 & & 27.9 & 1.63 & $* * *$ & -0.67 & $* *$ \\
\hline Swift near Roxbury & 251 & 1.43 & & 0.47 & & 26.5 & 2.43 & $* *$ & -1.02 & $*$ \\
\hline Little Androscoggin near S. Paris & 190 & 1.51 & $*$ & 0.94 & $*$ & 9.3 & 0.78 & & 0.84 & $*$ \\
\hline Saco at Conway, NH & 997 & 1.66 & & 0.84 & & 22.5 & 2.42 & $*$ & -0.72 & \\
\hline Saco at Cornish & 3349 & 2.04 & $* *$ & 0.75 & + & 17.2 & 1.35 & + & 0.77 & + \\
\hline Lamprey near Newmarket, $\mathrm{NH}$ & 474 & 3.12 & $* * *$ & 1.53 & $* *$ & 21.1 & 1.53 & + & 1.56 & $* *$ \\
\hline Merrimack at Lowell, MA & 11450 & 2.01 & $* *$ & 0.94 & $*$ & 32.8 & 2.34 & $* * *$ & -0.27 & \\
\hline
\end{tabular}

during the growing season (May-September) increased in 18 out of 22 basins, with the increases being statistically significant $(p<0.05)$ in nine of these basins (Table 2$)$. The basins with statistically significant increases in growing season temperature tended to be the same basins that had significant annual increasing trends in temperature. The trends in the basins showing decreasing average growing season temperature were not statistically significant.

Total annual precipitation increased in all basins throughout the period of record for runoff in each river basin (Table 3). The precipitation increases ranged from 0.9 to $3.1 \mathrm{~mm} \mathrm{yr}^{-1}$ and the median was $1.7 \mathrm{~mm} \mathrm{yr}^{-1}$. The trends toward increasing precipitation were statistically significant $(p<0.05)$ in 19 out of 22 basins. The basins without significant trends in precipitation tended to be in the southwestern part of the region. Precipitation during the growing season also increased in all basins over the period of record for runoff (Table 3 ). The increases ranged from 0.27 to $1.64 \mathrm{~mm} \mathrm{yr}^{-1}$ and the median was $0.73 \mathrm{~mm} \mathrm{yr}^{-1}$ - these trends were significant $(p<0.05)$ in 10 basins and marginally significant $(p<0.1)$ in three additional basins. The longer-term trends in precipitation (1895-2010) for each basin also indicated increasing total annual precipitation in all basins for this period (see Table S2, available as supplemental material at the Journals
Online website: http://dx.doi.org/10.1175/JHM-D-13-018.s2). For the periods of record for runoff, the average monthly trends in precipitation showed that precipitation increased in all months, except January, although the increases in February and September were small (Fig. 2). For the longer-term record (1895-2010), the monthly increases were generally large but there were decreases in precipitation in January, February, and March.

Total annual runoff also increased in all basins over the period of record and the increases varied from 0.67 to $2.6 \mathrm{~mm} \mathrm{yr}^{-1}$ (median $1.5 \mathrm{~mm} \mathrm{yr}^{-1}$ ) or $9 \%$ to $33 \%$ (Table 3). The increases in runoff were significant $(p<$ $0.05)$ in 12 basins and marginally significant $(p<0.1)$ in 6 other basins. Trends in total annual ET were less consistent, 16 sites had positive trends ( 6 of which were significant, $p<0.05$, and 3 marginally significant, $p<$ 0.1 ) and 6 had negative trends ( 3 were significant, $p<$ $0.05)$. For the 16 sites that had positive trends in ET the trends ranged from 0.25 to $1.6 \mathrm{~mm} \mathrm{yr}^{-1}$ (median $0.67 \mathrm{~mm} \mathrm{yr}^{-1}$ ). The five sites with negative trends in ET ranged from -0.15 to $-1.2 \mathrm{~mm} \mathrm{yr}^{-1}$ and the median for these sites was $-0.70 \mathrm{~mm} \mathrm{yr}^{-1}$.

The number of GDD per year increased significantly at most stations across the region (Table 4). Only two 


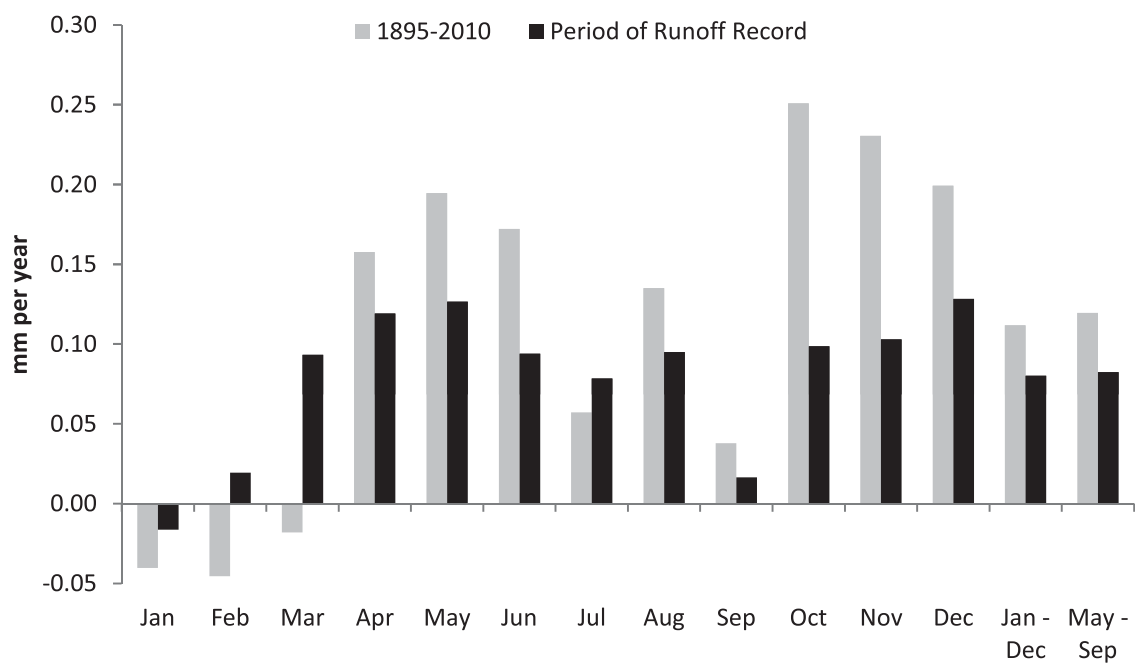

FIG. 2. Trends in monthly precipitation $\left(\mathrm{mm} \mathrm{yr}^{-1}\right)$ for each month, season, and annual period. Values are basin area-weighted for all non-nested basins (nested subbasins not included) and include data for 1895-2010 and for years corresponding to the period of record for runoff (see Table 1).

out of 15 stations showed decreasing trends in GDD and only one had a significant decrease. The number of growing degree days is related to warming during the growing season and increasing length of the growing season

\section{c. Temporal trends in temperature, precipitation, runoff, and ET for the nine largest non-nested basins}

When the data were aggregated for the nine largest nonnested basins for consistent time period 1927 through 2011 we observed significant increases in precipitation $\left(1.7 \mathrm{~mm} \mathrm{yr}^{-1}\right)$ and in runoff $\left(1.6 \mathrm{~mm} \mathrm{yr}^{-1}\right)$ (Table 5, Fig. 3). There were small positive trends toward increases in ET and in air temperature but these increases were not significant. For the more recent period 1970 through 2011 tests for trends in these variables for these nine basins showed substantially different results. There were positive trends in precipitation and runoff, but these trends were not statistically significant because of large interannual variability. There was a positive and significant trend in ET of $1.9 \mathrm{~mm} \mathrm{yr}^{-1}$

TABLE 4. Trends in growing degree days (GDD) (base 50 $\mathrm{F}$ ) for April through October at long-term record NOAA NCDC climate stations in Maine and New Hampshire. Data from Northeast Regional Climate Center, Cornell University, courtesy of Jessica Rennels. Significance levels for tests for Sen slopes $\neq 0$ ( $p$ values for: $* * *=<0.001, * *=<0.01, *=<0.05,+=<0.1$, blank $=>0.1$ ).

\begin{tabular}{|c|c|c|c|c|c|}
\hline Climate Station & Station ID & Period of record & Years of record ${ }^{\mathrm{a}}$ & Sen slope $\left(\mathrm{GDD}_{\mathrm{yr}}{ }^{-1}\right)$ & Significance \\
\hline Corrina, ME & 171628 & 1948-2010 & 60 & 2.44 & + \\
\hline Portland, ${ }^{\mathrm{b}} \mathrm{ME}$ & 176902,176905 & $1874-2011$ & 137 & 1.02 & $*$ \\
\hline Presque Isle, ME & 176937 & 1910-2010 & 96 & 3.49 & $* * *$ \\
\hline Farmington, ME & 172765 & 1893-2010 & 116 & -3.41 & $* * *$ \\
\hline Gardiner, ME & 173046 & $1893-2010$ & 110 & 0.03 & \\
\hline Eastport, ME & 172426 & 1893-2010 & 112 & 5.35 & $* * *$ \\
\hline Millinocket, ME & 175304 & 1903-2009 & 103 & 0.67 & \\
\hline Caribou, ME & 171175 & 1939-2011 & 73 & 3.19 & $* *$ \\
\hline Hanover, NH & 273850 & $1893-2010$ & 114 & 3.86 & $* * *$ \\
\hline Keene, NH & 274399 & 1893-2010 & 117 & 3.29 & $* * *$ \\
\hline First Connecticut Lake, NH & 272999 & $1930-2011$ & 81 & -1.14 & \\
\hline Rangeley, ME & 177037 & 1970-2011 & 42 & 4.00 & + \\
\hline Berlin, NH & 270690 & $1918-2011$ & 90 & 1.97 & $* *$ \\
\hline Bangor, ME & 170355 & 1953-2011 & 56 & 4.71 & $* *$ \\
\hline Houlton, ME & 173892 & $1949-2011$ & 60 & 0.79 & \\
\hline
\end{tabular}

\footnotetext{
${ }^{\text {a }}$ Years in the period of record that passed completeness criterion $<15$ missing daily values (during April through October), missing values were estimated in these annual summations.

${ }^{\mathrm{b}}$ Portland Intl Airport, 176902 (1941-2010) combined with Portland, 176905 (1875-1940).
} 
TABLE 5. Trends in annual precipitation, runoff, evapotranspiration, and air temperature for selected time periods and for non-nested basins where the data were aggregated using area-weighting. All periods begin with indicated start year and continue to 2011 and are for water years (1 Oct of prior year to 30 Sep of indicated year). Significance levels for tests for Sen slopes $\neq 0$ ( $p$ values for: $* * *=<0.001$, $* *=<0.01, *=<0.05,+=<0.1, \mathrm{NS}=>0.1)$

\begin{tabular}{lcccc}
\hline \hline \multicolumn{1}{c}{ Variable } & Start water year & End water year & Slope & Significance \\
\hline Precipitation & 1927 & 2011 & $1.7 \mathrm{~mm} \mathrm{yr}^{-1}$ & $1.6 \mathrm{~mm} \mathrm{yr}^{-1}$ \\
Runoff & 1927 & 2011 & $0.18 \mathrm{~mm} \mathrm{yr}^{-1}$ & $*$ \\
ET & 1927 & 2011 & $0.003^{\circ} \mathrm{C} \mathrm{yr}^{-1}$ & $\mathrm{NS}$ \\
Air temperature & 1927 & 2011 & $2.86 \mathrm{~mm} \mathrm{yr}^{-1}$ & $\mathrm{NS}$ \\
Precipitation & 1970 & 2011 & $0.93 \mathrm{~mm} \mathrm{yr}^{-1}$ & $\mathrm{NS}$ \\
Runoff & 1970 & 2011 & $1.93 \mathrm{~mm} \mathrm{yr}^{-1}$ & NS \\
ET & 1970 & 2011 & $0.014^{\circ} \mathrm{Cyr}^{-1}$ & $*$ \\
Air temperature & 1970 & 2011 & & + \\
\hline
\end{tabular}

$(p<0.01)$ and a positive but not statistically significant trend in air temperature of $0.014^{\circ} \mathrm{C} \mathrm{yr}^{-1}(p<0.1)$ (Table 5). Only a small fraction of the trend in the difference between precipitation and runoff that we attribute to ET for this more recent period (1970-2011) could be explained by an increase in groundwater storage. To estimate the proportion of the increase in ET that could be explained by an increase in groundwater storage we used the reported groundwater level increases reported by WB2010. We used specific yield (the volumetric fraction of the bulk aquifer volume that a given aquifer will yield when all the water is allowed to drain out of it under the forces of gravity) for glacial till (11\%) (Johnson 1967) and sand and gravel aquifers (10\%)

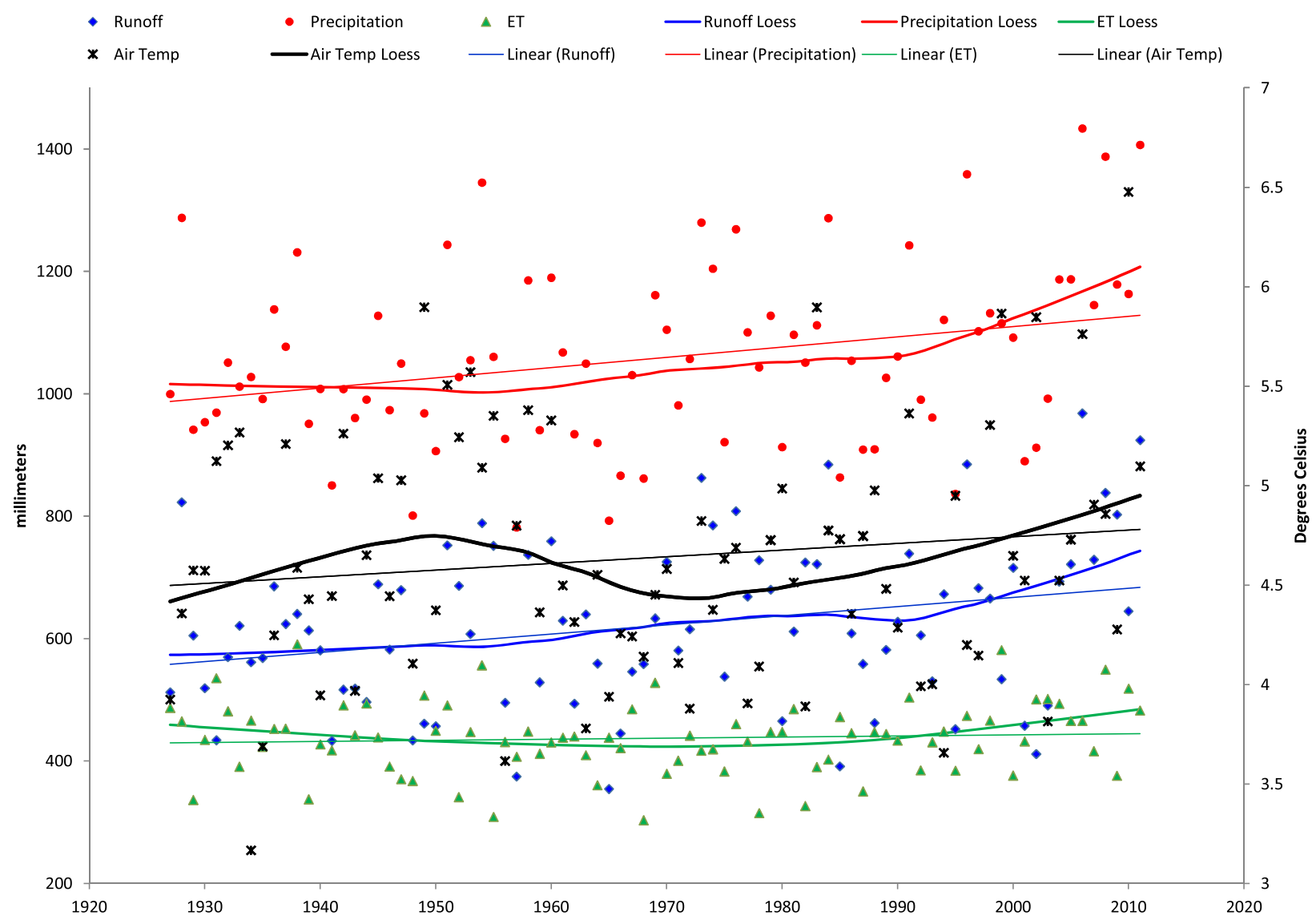

FIG. 3. Precipitation (PPT, red), runoff (blue), evapotranspiration (ET, green), and temperature (black) time series for the areaweighted averages for the nine largest non-nested basins in this study for the period 1926-2010. Linear regressions and LOESS smooths are shown for each variable. 
TABLE 6. Kendall correlations $(\tau)$ between average annual precipitation and average annual temperature and between average growing season precipitation and average growing season temperature. Boldface indicates significant correlation at $p<0.05$.

\begin{tabular}{|c|c|c|c|c|c|}
\hline \multirow[b]{2}{*}{ Basin } & \multirow{2}{*}{$\begin{array}{l}\text { Number of years } \\
(n)\end{array}$} & \multicolumn{2}{|c|}{$\begin{array}{c}\text { Average annual } \\
\text { precipitation vs average } \\
\text { annual temperature }\end{array}$} & \multicolumn{2}{|c|}{$\begin{array}{l}\text { Average growing season } \\
\text { precipitation vs average } \\
\text { growing season temperature }\end{array}$} \\
\hline & & Kendall $(\tau)$ & $p$ value & Kendall $(\tau)$ & $p$ value \\
\hline St. John at Fort Kent & 85 & 0.10 & 0.16 & -0.05 & 0.47 \\
\hline Aroostook at Washburn & 81 & 0.12 & 0.10 & -0.05 & 0.53 \\
\hline St. Croix at Baring & 91 & 0.23 & 0.001 & 0.04 & 0.53 \\
\hline Penobscot at West Enfield & 109 & 0.12 & 0.06 & 0.03 & 0.65 \\
\hline Kennebec at the Forks & 108 & 0.13 & 0.04 & 0.03 & 0.70 \\
\hline Carrabassett near North Anson & 86 & 0.16 & 0.03 & 0.04 & 0.60 \\
\hline Androscoggin at Rumford & 110 & 0.15 & 0.02 & 0.09 & 0.18 \\
\hline Saco at Cornish & 95 & 0.16 & 0.02 & 0.06 & 0.38 \\
\hline Merrimack at Lowell & 88 & 0.14 & 0.04 & 0.07 & 0.31 \\
\hline
\end{tabular}

from Gerber and Hebson (1996). We used $11 \%$ for glacial till assuming that the glacial till in this region is a mixture of coarse and finer grained materials. We used area-weighted averages based on $93 \%$ glacial till and $7 \%$ sand and gravel (includes stratified drift, unconsolidated glacial deposits, and glacial outwash) based on Falcone et al. (2010), Kontis et al. (2004), and Dudley (2004). With these assumptions and the rates of groundwater level increases reported by WB2010, for an average period of 1969 to 2009, we found that an increase in groundwater storage could explain only $10 \%$, at most, of the $1.9 \mathrm{~mm} \mathrm{yr}^{-1}$ increase in ET that we calculated for 1970 to 2011.

This estimate of $10 \%$ is a conservative estimate for several reasons. A substantial proportion of the glacial till in Maine is classified as thin $(<3 \mathrm{~m}$ thickness) and contains numerous rock outcrops (http://www.maine. gov/doc/nrimc/mgs/pubs/online/surficial.htm) and occurs on sloping terrain in hilly and mountainous areas and therefore may not be water bearing. Kontis et al. (2004) have noted that even for the areas mapped as stratified-drift aquifers (sand and gravel aquifers), "many of the larger tracts are perched above stream grade along mountain fronts, and are therefore largely unsaturated," and many areas that are mapped as sand and gravel are thin and fine grained and may not be saturated. Finally, only 3 of the 14 wells drilled in till that were studied by WB2010 showed increases in groundwater level. These wells were in Massachusetts and were close to rivers and therefore not representative of the till in the study area.

\section{d. Correlation analysis}

For most of the largest non-nested basins there were significant positive correlations between average annual precipitation and average-annual surface air temperature for the period of runoff record (Table 6). Correlations were not significant between average growing season precipitation and average growing season surface-air temperature for the period of runoff record.

The correlations between annual ET and annual temperature for the nine largest non-nested basins were generally positive but significant $(p<0.01)$ for only one river basin (St. Croix at Baring) (data not shown). The correlations between annual ET and growing season temperature for the nine largest non-nested basins were positive for 6 out of 9 basins, but significant $(p<0.01)$ for only the St. Croix River at Baring).

Annual average ET in each of the 19 basins studied was positively and significantly correlated $(p<0.05)$ with percent forest, percent deciduous forest, and percent evergreen forest and negatively and significantly correlated with percent open water (Table 7). There were no significant correlations between annual average ET and basin-average soil water infiltration, drainage properties, texture, bulk density, or soil thickness (data not shown). A significant negative correlation $(p<0.05)$ was observed between trend in annual ET and percent deciduous forest (Table 7). There were no significant correlations between the trend in annual ET and the soil variables tested.

\section{Discussion}

The observed changes in air temperature in the river basins over the periods of runoff record studied vary considerably from $-0.2^{\circ}$ to $1.9^{\circ} \mathrm{C}(100 \mathrm{yr})^{-1}$. The two sites showing a temperature decrease had shorter than average periods of record, beginning 1929 and 1932. The area-weighted average change over time for the nonnested basins was $0.3^{\circ} \mathrm{C}(100 \mathrm{yr})^{-1}$. This increase was similar to the increase reported by Keim et al. (2003) for the period 1931-2000 and smaller than the increases reported by Trombulak and Wolfson (2004) for the 
TABLE 7. Nonparametric Kendall correlations $(\tau)$ tests between annual ET and trend in ET and land cover variables for 19 of the 22 basins (where the entire drainage is in the United States). Boldface indicates significant correlation at $p<0.05$.

\begin{tabular}{|c|c|c|c|c|}
\hline \multirow[b]{2}{*}{ Variable (\%) } & \multicolumn{2}{|c|}{ Annual ET } & \multicolumn{2}{|c|}{ Trend in annual ET } \\
\hline & Kendall $(\tau)$ & $p$ value & Kendall $(\tau)$ & $p$ value \\
\hline Forest & 0.43 & 0.001 & -0.12 & 0.46 \\
\hline Agriculture & -0.09 & 0.59 & 0.10 & 0.53 \\
\hline Open water & -0.40 & 0.02 & 0.16 & 0.33 \\
\hline Deciduous forest & 0.36 & 0.03 & -0.38 & 0.02 \\
\hline Evergreen forest & 0.34 & 0.04 & -0.22 & 0.19 \\
\hline Mixed forest & -0.29 & 0.08 & 0.30 & 0.07 \\
\hline Shrubland & -0.15 & 0.36 & 0.09 & 0.60 \\
\hline Grassland & -0.21 & 0.19 & 0.18 & 0.29 \\
\hline Pasture hay & -0.11 & 0.51 & 0.01 & 0.94 \\
\hline Cultivated crops & 0.01 & 0.94 & 0.03 & 0.86 \\
\hline Wooded wetland & -0.23 & 0.16 & 0.06 & 0.70 \\
\hline Herbaceous wetland & -0.11 & 0.51 & 0.32 & 0.06 \\
\hline Depth to seasonally high water table & 0.27 & 0.11 & -0.12 & 0.46 \\
\hline Soil organic matter content & -0.15 & 0.38 & 0.00 & 1.00 \\
\hline
\end{tabular}

twentieth century, ranging from $1^{\circ}$ to $2^{\circ} \mathrm{C}(100 \mathrm{yr})^{-1}$, except for northern Maine where Trombulak and Wolfson reported an increase in the range of $0^{\circ}$ to $1^{\circ} \mathrm{C}(100 \mathrm{yr})^{-1}$. In our study, we also found the smallest temperature increases (or decreases) in the northernmost basins (such as Allagash, St. John, Aroostook, and Mattawamkeag). The average temperature increase for the non-nested basins for the more recent period (1970-2011) was $1.4^{\circ} \mathrm{C}$ $(100 \mathrm{yr})^{-1}$. This substantially higher rate of warming after 1970 is in close agreement with the findings reported for the northeast region using USHCN stationbased data (Hayhoe et al. 2007).

Our data for air temperature trends are generally consistent with those of Trombulak and Wolfson (2004), Keim et al. (2003), and Hayhoe et al. (2007) and the differences are likely due to different time periods, different areas, and the fact that we used the PRISM data whereas the other studies used USHCN station data. The temperature trends for the full period of record (1895-2010) using the PRISM data were positive ( $p<$ 0.05 ) for all but one basin (data not shown). The reported increases in GDD are consistent with those reported for Atlantic Canadian provinces bordering the study region from 1900 through 1998 (Bonsal et al. 2001). The fact that minimum temperatures increased more than maximum temperatures is consistent with a decrease in the diurnal temperature range (DTR). A decrease in DTR has been reported for the northeastern United States (Lauritsen and Rogers 2012). The decrease in DTR is also consistent with an increase in cloudiness over this region (Lauritsen and Rogers 2012).

Increases in precipitation in this region during the twentieth century have been previously reported based on USHCN station data (Keim et al. 2005; Hayhoe et al.
2007). Increasing precipitation and runoff in the eastern United States after 1970 could be a response to a persistent change in the NAO from negative to positive (McCabe and Wolock 2011b); however, the association of precipitation with the positive phase of the NAO is limited to winter (Hurrell 1995; Bradbury et al. 2003; Durkee et al. 2008) and, for this region, winter precipitation decreased from 1900 to 1999 (Hayhoe et al. 2007). A test for correlations between 3 -month average NAO index and corresponding 3-month average total precipitation for the river basins studied in Maine for 1950 through 2010 for winter only and for annual periods revealed no correlations (data not shown). Increasing precipitation for this region is consistent with projections of climate models (Hayhoe et al. 2007; Bates et al. 2008 ) and with a warming-induced intensification of the hydrologic cycle (Huntington 2010).

The positive trends toward increasing runoff observed in this study are consistent with the generally increasing trends in runoff reported in earlier studies in New England (WB2010) and in the conterminous United States (McCabe and Wolock 2002), albeit for different sets of basins and time periods. Discharge has also increased in the St. John River near Mactaquac Dam, New Brunswick, since 1919, where the drainage area is $39900 \mathrm{~km}^{2}$ (http://www.wsc.ec.gc.ca/applications/ $\mathrm{H} 2 \mathrm{O} /$ index-eng.cfm; Michael Chiasson, New Brunswick Power, Mactaquac Dam, 2012, personal communication).

The observed trends in ET were positive for most (16 out of 22) basins but these trends were statistically significant in only six basins. We expected to observe increasing ET based on previous studies that had shown increasing surface air temperatures, lengthening growing season, and no obvious decrease in summertime 
precipitation or decrease in soil moisture (Hayhoe et al. 2007). An increase in ET was also expected based on recent modeling that predicts increasing precipitation and increasing ET (by about $8 \%$ ) throughout this region when comparing 2021-40 to 1951-2000 (Seager et al. 2013). Other recent modeling studies have indicated that runoff efficiency (ratio of annual runoff to annual precipitation) may have decreased in recent years as a result of increases in temperature that resulted in an increase in ET (Bounoua et al. 2010; McCabe and Wolock 2011a; Gerten et al. 2008). These studies may be taken as indirect support for the possibility that ET might have increased in recent decades.

The aggregated data for the consistent period 19272011 using area-weighted averages for the nine largest non-nested basins showed that precipitation increased at a faster rate than did runoff implying a small, but not statistically significant, increase in ET (Fig. 3). We expected a larger increase in ET based on previous studies showing increases in surface air temperature and lengthening of the growing season and the aforementioned modeling studies. The response of these Gulf of Maine basins to increasing precipitation throughout this period differed from the response of the large river basins in the United States that Walter et al. (2004) studied from 1950 to 2000, where precipitation increased faster than runoff ( 1.49 vs $0.39 \mathrm{~mm} \mathrm{yr}^{-1}$ ). However, Campbell et al. (2011) reported increasing precipitation and runoff but slightly declining ET for four small (13 to 77 ha) watersheds at the Hubbard Brook Experimental Forest in New Hampshire beginning between 1959 to 1969 and ending in 2008. Streamflow response to increasing precipitation can be described as the proportional change in streamflow to the proportional change in precipitation (Sankarasubramanian and Vogel 2003). Sankarasubramanian and Vogel (2003) reported that for unregulated basins in the Gulf of Maine watershed in the United States that for a $1 \%$ increase in precipitation streamflow would increase between $1 \%$ and $1.5 \%$ for most of our study region and between $1.5 \%$ and $2.5 \%$ for the southwestern part of our study region. Their analysis period was from 1951-88. Our analysis involved some basins that had regulated flows. On an annual basis, flow regulation does not affect streamflow amounts to any appreciable extent because interannual changes in storage are much smaller than runoff volumes. In our analysis of the nine largest non-nested basins for 1927-2011 the comparable change was a $2 \%$ increase in streamflow for each $1 \%$ increase in precipitation. This observed streamflow response to increasing precipitation is somewhat higher than what would be expected for this region based on Sankarasubramanian and Vogel (2003), and it is consistent with the fact that ET did not increase more consistently over this period. An increase in ET would have muted the streamflow response.

The explanation for the trends observed in Gulf of Maine river basins may be related to other factors that may have suppressed actual ET over this region. Various trends in environmental conditions can complicate the potential ET response to increases in surface air temperature. It has been reported that wind speeds have decreased over many land areas including the northeastern United States (Wang et al. 2010; McVicar et al. 2012) and decreasing wind speeds tend to decrease the rate of ET. There is also evidence that cloudiness increased over this region in recent decades (Lauritsen and Rogers 2012) and increases in cloudiness reduce solar radiation that then reduce the rate of vegetation growth and transpiration. Global dimming (a decrease in incident solar radiation) between the 1950s and 1980s, followed by a period of partial recovery (i.e., brightening) beginning in the 1990s, has been reported (Wild 2009), which may also have decreased the rate of plant growth, transpiration, and ET prior to the 1980s. More recently, after 1990, brightening is consistent with enhanced ET over global land areas (Wang et al. 2010). Finally, anthropogenic aerosol-induced atmospheric cooling during the 1950s and 1960s (Wilcox et al. 2013) may have suppressed intensification of the hydrologic cycle during that period (Ramanathan et al. 2001; Wu et al. 2013), thereby reducing the longer-term trends in precipitation and ET.

Reported trends toward increasing atmospheric water vapor content or specific humidity (Willett et al. 2008) are consistent with a decrease in vapor pressure deficit that drives the gradient between the interior of leaf stomata and the atmosphere. An increase in specific humidity would tend to depress ET. Hobbins et al. (2004) reported a trend toward increasing solar radiation, but mixed trends in vapor pressure deficit for 1953 to 1994 in our study area. Most of north and central Maine had decreasing vapor pressure deficit (Hobbins et al. 2004) that would tend to decrease ET. Sanford and Selnick (2013) used a water-balance approach to estimate ET using 838 streamgages across the United States during 1971-2000, and developed regression equations to estimate ET by county. Along the east coast of the United States, it is evident that runoff is greater closer to the coast than in adjacent counties inland due to high precipitation and presumably to the effect of high humidity suppressing ET. In these coastal counties the diurnal temperature range is generally lower (Sanford and Selnick 2013) than inland, which is consistent with high humidity.

Increases in atmospheric concentrations of ozone and $\mathrm{CO}_{2}$, and decreases in the rate of forest growth could also have affected the rate of ET in recent decades. 


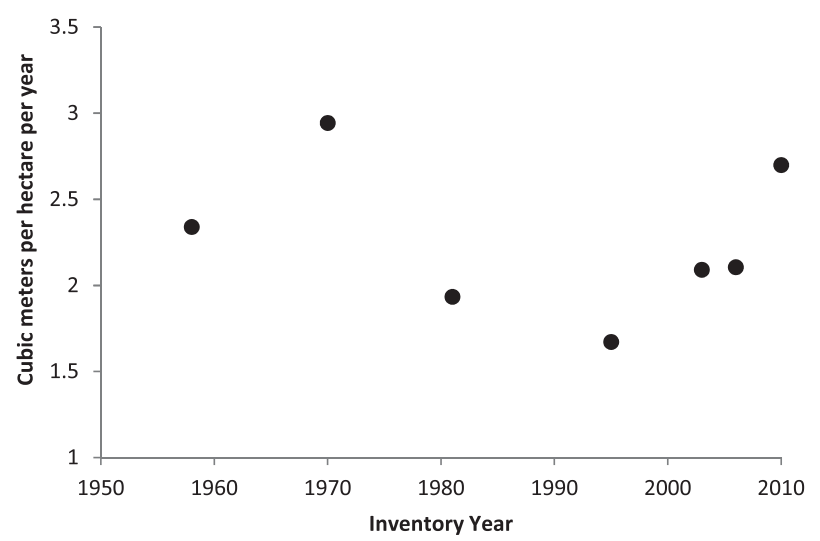

FIG. 4. Net increease of growing stock timber (merchantable volume) on timberland in Maine based on U.S. Forest Service Forest Inventory and Analysis (FIA) data.

Atmospheric ozone can have a variety of effects on plants including damage to foliage and overall growth (Felzer et al. 2007) thereby reducing ET, or a reduction in stomatal control that could lead to an increase in ET (Sun et al. 2012). The observed increases in atmospheric $\mathrm{CO}_{2}$ could lead to suppression of transpiration and reduced ET (Field et al. 1995). The rate of forest growth decreased in Maine from the 1950s to the early 2000s (Fig. 4), attributable largely to insect damage and forest harvesting practices (Gadzik et al. 1998), but soil calcium depletion cannot be ruled out (Huntington 2005).

Increases in daily minimum temperatures have been substantially larger than increases in maximum temperatures (Lauritsen and Rogers 2012), indicating that nighttime temperatures increased more than daytime temperatures. This pattern of temperature increases could mute the effect of the overall increase in temperature on ET because increases in nighttime temperature would have less influence on transpiration than increases in daytime temperature. Increases in minimum temperatures explain the trend toward a decreasing DTR in the northeast United States (Lauritsen and Rogers 2012). Decreases in DTR in the northeastern United States have been closely associated with increasing cloud cover, and cloud cover accounts for $63 \%$ of the regional annual variability in DTR (Lauritsen and Rogers 2012; Sanford and Selnick 2013). As noted, the increases in cloud cover would reduce solar radiation, and potentially photosynthesis and ET. The increase in GDD may also be largely attributed to the decrease in minimum temperatures, as reported by Bonsal et al. (2001) for Canada, rather than an increase in maximum temperatures or an expansion of the growing season resulting in less influence on ET.

Over the period of record for discharge the most important change in land use was an increase in forest cover on formerly agricultural land. Irland (1998) estimated between $68 \%$ and $77 \%$ forest cover in Maine around 1900 , around $75 \%$ by 1930 , and around $90 \%$ by 1971 and constant thereafter. Land-cover changes in the Merrimack and Lamprey River basins were probably similar until 1983 when they reached a postsettlement maximum of above $85 \%$ forested (Jeon et al. 2014). Land-use conversions from forest to other land uses have been more extensive in recent decades in New Hampshire than in Maine. The Merrimack River basin was estimated to be $70 \%$ forested and the Lamprey River basin was $73 \%$ forested in 2001 (Falcone et al. 2010). Land-use conversion from agricultural land to forest land would typically be associated with a decrease in runoff if precipitation were held constant because transpiration rates and evaporation from forest canopies are generally higher than on agricultural land (Schneider and Ayer 1961; Hornbeck et al. 1997). Increases in runoff may have actually been somewhat higher than we observed if the area had not experienced this increase in forestation.

Our observations of significant correlations between annual temperature and annual precipitation for most basins are consistent with a warming-induced intensification of the hydrologic cycle (Huntington, 2006, 2010). Wetter conditions are expected at the global scale, but large regional variations in trends in precipitation have been observed and are likely to persist with continued warming (Bates et al. 2008). Our observations for basins draining to the Gulf of Maine contrast with the findings of Déry and Wood (2005), who reported positive correlations between temperature and precipitation in some land areas at high latitudes $\left(>\sim 50^{\circ} \mathrm{N}\right)$ and no, or negative, correlations from the equator to $50^{\circ} \mathrm{N}$. The Déry and Wood (2005) study looked at 1901 to 2000, whereas our average time period was 1927 to 2011 and our study area extended from about $41^{\circ}$ to $48^{\circ} \mathrm{N}$, or just south of the region for which Déry and Wood (2005) reported some positive annual correlations.

Trenberth (2011) reported that some areas, including Maine, exhibited a positive correlation between air temperature and precipitation from November through March but an anticorrelation from May through September (1979-2002). In contrast, we found no correlation between air temperature and precipitation during the growing season (May-September). This difference in the growing season response could simply be a result of our substantially longer study period or the differences in the gridded temperature and precipitation data. We found no relation between basins that had significant positive trends in growing season temperature and those that had significant positive trends in growing season precipitation (Tables 2 and 3). Basins experiencing the 
largest increases in precipitation during the growing season may have had their potential temperature increases dampened through reduced insolation and increased evaporative cooling associated with high precipitation. This phenomenon of precipitation dampening a temperature increase is characteristic of the anticorrelation between surface air temperature and precipitation observed in some locations (Trenberth and Shea 2005; Déry and Wood 2005). However, we did not find significant anticorrelation between growing season temperature and precipitation when all basins were considered.

It was surprising that only the St. Croix River at Baring showed a significant positive correlation between annual average temperature and annual average ET. Although the correlation between annual average ET and annual average temperature was only significant for the St. Croix River, all but one of the nine largest nonnested basins showed positive correlations. When the data were aggregated for the nine largest non-nested basins and from 1927 through 2011 by using areaweighted averages the correlation between annual average ET and annual average air temperature was positive and significant with a $p$ value $=0.001$. The positive correlation was consistent with our hypothesis that increasing temperatures in the historical period would be associated with increasing rates of ET and is consistent with other studies that indicated ET may be increasing in response to increasing temperature in this region (Bounoua et al. 2010; McCabe and Wolock 2011a; Gerten et al. 2008).

Our observations of generally increasing ET over the entire periods of record in this study area are consistent with increasing air temperature and precipitation and the ongoing lengthening of the growing season. It would appear that soil moisture availability is not usually a limiting factor to ET because ET is generally increasing and precipitation is increasing. Increases in ET in association with lengthening of the growing season is consistent with measurement and modeling studies that have indicated that earlier leaf out and later senescence can increase ET in forested ecosystems (White et al. 1999; Kljun et al. 2006; Brümmer et al. 2012).

The positive correlations between annual average ET and percent total forest, deciduous forest, and evergreen forest is consistent with higher ET measured from forested land covers than ET from cultivated crops or most other land uses. The lack of correlations observed between annual average ET and most other land cover variables may be due to their relatively small abundance on the landscape in this largely forested region. The negative correlation between annual average ET and percent open water was unexpected and cannot be explained with our data.

\section{Conclusions}

Analysis of climatological and hydrologic time series data for 22 river basins in the United States that drain to the Gulf of Maine that have more than 70 years of continuous discharge records showed significant trends that are consistent with a warming-induced intensification of the hydrologic cycle. Trends in annual average temperature increased over the period of runoff record for 20 of 22 basins. Trends in annual average precipitation and runoff increased in all basins. Evapotranspiration (ET) (calculated as precipitation minus runoff, neglecting minor changes in terrestrial water storage) increased in 16 basins and decreased in 6 basins. Annual average temperature and annual average precipitation were positively correlated for most of the largest basins. The trends in annual average evapotranspiration were only weakly positively correlated with the trend in annual average temperature for each individual basin, but this trend was positive and significant for the region as a whole from 1927 to 2011. The lack of a more consistent and steeper increase in ET over time was unexpected but could be explained by various factors including decreases in wind speed, solar radiation, and plant growth, increases in cloudiness, specific humidity, ozone, and atmospheric $\mathrm{CO}_{2}$ concentrations, any of which could have reduced the rate of evaporation or transpiration.

The results from this study are consistent with theoretical and climate modeling projections for hydrologic changes that are likely to occur in response to an ongoing warming of surface air temperature. Future research is needed on the potential effects of changes in specific humidity, wind speed, atmospheric ozone and $\mathrm{CO}_{2}$ concentrations, cloudiness and insolation, forest growth rates, and land-use conversions on ET to improve our understanding and ability to model how projected climate warming will influence ET and streamflow.

Acknowledgments. We gratefully acknowledge the assistance with data collection over many years by dedicated hydrologic technicians working with the U.S. Geological Survey and Environment Canada. Primary funding for this work was generously provided to T. G. Huntington by NASA (Grants NNH12AT17I, NNH04 AA66I, and NNH08A157I). Additional support was provided by the U.S. Geological Survey's funds for the study of Climate and Land Use Change. We wish to thank Ward Sanford (U.S. Geological Survey) and three anonymous reviewers for their reviews of earlier drafts of this paper. Any use of trade, firm, or product names is for descriptive purposes only and does not imply endorsement by the U.S. Government. 


\section{REFERENCES}

Anderson, B. T., K. Hayhoe, and X.-Z. Liang, 2010: Anthropogenicinduced changes in twenty-first century summertime hydroclimatology of the northeastern US. Climatic Change, 99, 403423, doi:10.1007/s10584-009-9674-3.

Armstrong, D. S., 1996: Maine wetland resources. National Water Summary on Wetland Resources, USGS Water Supply Paper 2425, 213-218.

Bates, B. C., Z. W. Kundzewicz, S. Wu, and J. P. Palutikof, Eds., 2008: Climate change and water. IPCC Tech. Paper VI, 210 pp. [Available online at https://www.ipcc.ch/publications_and data/publications_and_data_technical_papers.shtml.]

Berbery, E. G., and V. R. Barros, 2002: The hydrologic cycle of the La Plata Basin in South America. J. Hydrometeor., 3, 630-645, doi:10.1175/1525-7541(2002)003<0630:THCOTL >2.0.CO;2.

Bonsal, B. R., X. Zhang, L. A. Vincent, and W. D. Hogg, 2001: Characteristics of daily and extreme temperatures over Canada. J. Climate, 14, 1959-1976, doi:10.1175/1520-0442(2001) 014<1959:CODAET $>2.0 . \mathrm{CO} ; 2$.

Bounoua, L., F. G. Hall, P. J. Sellers, A. Kumar, G. J. Collatz, C. J. Tucker, and M. L. Imhoff, 2010: Quantifying the negative feedback of vegetation to greenhouse warming: A modeling approach Geophys. Res. Lett., 37, L23701, doi:10.1029/2010GL045338.

Bradbury, J. A., B. D. Keim, and C. Wake, 2003: Influence of regional storm tracking and teleconnections on winter precipitation in the northeastern United States. Ann. Amer. Soc Geogr., 93, 544-556, doi:10.1111/1467-8306.9303002.

Brümmer, C., and Coauthors, 2012: How climate and vegetation type influence evapotranspiration and water use efficiency in Canadian forest, peatland and grassland ecosystems. Agric. For. Meteor., 153, 14-30, doi:10.1016/j.agrformet.2011.04.008.

Campbell, J. L., C. T. Driscoll, A. Pourmokhtarian, and K. Hayhoe, 2011: Streamflow responses to past and projected future changes in climate at the Hubbard Brook Experimental Forest, New Hampshire, United States. Water Resour. Res., 47, W02514, doi:10.1029/2010WR009438.

Cember, R. P., and D. S. Wilks, 1993: Climatological atlas of snowfall and snow depth for the northeastern United States and southeastern Canada. Northeast Regional Climate Center Publication RR 93-1, 213 pp.

Cheng, L., Z. Xu, D. Wang, and X. Cai, 2011: Assessing interannual variability of evapotranspiration at the catchment scale using satellite-based evapotranspiration data sets. Water Resour. Res., 47, W09509, doi:10.1029/2011WR010636.

Cleveland, W. S., and S. J. Devlin, 1988: Locally-weighted regression: An approach to regression analysis by local fitting. J. Amer. Stat. Assoc., 83, 596-610, doi:10.1080/ 01621459.1988.10478639.

Daly, C., W. Gibson, G. Taylor, G. L. Johnson, and P. Pasteris, 2002: A knowledge-based approach to the statistical mapping of climate. Climate Res., 22, 99-113, doi:10.3354/cr022099.

, M. Halbleib, J. I. Smith, W. P. Gibson, M. K. Doggett, G. H. Taylor, J. Curtis, and P. P. Pasteris, 2008: Physiographically sensitive mapping of climatological temperature and precipitation across the conterminous United States. Int. J. Climatol., 28, 2031-2064, doi:10.1002/joc.1688.

Déry, S. J., and E. F. Wood, 2005: Observed twentieth century land surface air temperature and precipitation covariability. Geophys. Res. Lett., 32, L21414, doi:10.1029/2005GL024234.

Domokos, M., and J. Sass, 1990: Long-term water balances for subcatchments and partial national areas in the Danube basin J. Hydrol., 112, 267-292, doi:10.1016/0022-1694(90)90019-T.
Douville, H., A. Ribes, B. Decharme, R. Alkama, and J. Sheffield, 2013: Anthropogenic influence on multidecadal changes in reconstructed global evapotranspiration. Nat. Climate Change, 3, 59-62, doi:10.1038/nclimate1632.

Dragoni, D., and A. F. Rahman, 2012: Trends in fall phenology across the deciduous forests of the eastern USA. Agric. For. Meteor., 157, 96-105, doi:10.1016/j.agrformet.2012.01.019.

Dudley, R. W., 2004, Estimating monthly, annual, and low 7-day, 10 -year streamflows for ungaged rivers in Maine. U.S. Geological Survey, Scientific Investigations Report 2004-5026, $22 \mathrm{pp}$.

Durbin, J., and G. S. Watson, 1971: Testing for serial correlation in least squares regression. III. Biometrika, 58, 1-19.

Durkee, J. D., J. D. Frye, C. M. Fuhrmann, M. C. Lacke, H. G. Jeong, and T. L. Mote, 2008: Effects of the North Atlantic Oscillation on precipitation-type frequency and distribution in the eastern United States. Theor. Appl. Climatol., 94, 51-65, doi:10.1007/s00704-007-0345-x.

Falcone, J. A., D. M. Carlisle, D. M. Wolock, and M. R. Meador, 2010: GAGES: A stream gage database for evaluating natural and altered flow conditions in the conterminous United States. Ecology, 91, 621, doi:10.1890/09-0889.1.

Felzer, B. S., T. Cronin, J. M. Reilly, J. M. Melillo, and X. Wang, 2007: Impacts of ozone on trees and crops. C. R. Geosci., 339, 784-798, doi:10.1016/j.crte.2007.08.008.

Ferguson, C. R., J. Sheffield, E. F. Wood, and H. Gao, 2010: Quantifying uncertainty in a remote sensing-based estimate of evapotranspiration over continental USA. Int. J. Remote Sens., 31, 3821-3865, doi:10.1080/01431161.2010.483490.

Field, C. B., R. B. Jackson, and H. A. Mooney, 1995: Stomatal response to increased $\mathrm{CO}_{2}$ : Implications from the plant to the global scale. Plant Cell Environ., 18, 1214-1225, doi:10.1111/ j.1365-3040.1995.tb00630.x.

Gadzik, C. J., J. H. Blanck, and L. E. Caldwell, 1998: Timber supply outlook for Maine: 1995-2045. Maine Forest Service Department of Conservation Rep., 39 pp.

Gao, H., Q. Tang, C. R. Ferguson, E. F. Wood, and D. P. Lettenmaier, 2010: Estimating the water budget of major US river basins via remote sensing. Int. J. Remote Sens., 31, 3955-3978, doi:10.1080/ 01431161.2010.483488.

Garcia, N. O., and C. R. Mechoso, 2005: Variability in the discharge of South American rivers and in climate. Hydrol. Sci. J., 50, 459-478, doi:10.1623/hysj.50.3.459.65030.

Gerber, R. G., and C. S. Hebson, 1996: Ground water recharge rates for Maine soils and bedrock. Selected Papers on the Hydrogeology of Maine, Bull. 4, M. C. Loiselle, Ed., Geological Society of Maine, 23-51.

Gerten, D., S. Rost, W. von Bloh, and W. Lucht, 2008: Causes of change in 20th century global river discharge. Geophys. Res. Lett., 35, L20405, doi:10.1029/2008GL035258.

Griffith, D. M., and C. L. Alerich, 1996: Forest statistics for Maine, 1995. Resource Bull. NE-135, U.S. Department of Agriculture, Northeastern Forest Experiment Station, 134 pp.

Hayhoe, K., and Coauthors, 2007: Past and future changes in climate and hydrological indicators in the US Northeast. Climate Dyn., 28, 381-407, doi:10.1007/s00382-006-0187-8.

Healy, R. W., T. C. Winter, J. W. LaBaugh, and O. L. Franke, 2007: Water budgets: Foundations for effective water resources and environmental management. U.S. Geological Survey Circular 1308, 90 pp.

Held, I. M., and B. J. Soden, 2000: Water vapor feedback and global warming. Annu. Rev. Energy Environ., 25, 441-475, doi:10.1146/ annurev.energy.25.1.441. 
— and - 2006: Robust responses of the hydrological cycle to global warming. J. Climate, 19, 5686-5699, doi:10.1175/JCLI3990.1.

Hirsch, R. M., 1982: A comparison of four streamflow record extension techniques. Water Resour. Res., 18, 1081-1088, doi:10.1029/ WR018i004p01081.

Hobbins, M. T., J. A. Ramírez, and T. C. Brown, 2004: Trends in pan evaporation and actual evapotranspiration across the conterminous U.S.: Paradoxical or complementary? Geophys. Res. Lett., 31, L13503, doi:10.1029/2004GL019846.

Hodgkins, G. A., 1999: Estimating the magnitude of peak flows for streams in Maine for selected recurrence intervals. U.S. Geological Survey Water Resources Investigation Rep. 994008, 45 pp.

—-, and R. W. Dudley, 2005: Changes in the magnitude of annual and monthly streamflows in New England, 1902-2002. USGS Scientific Investigations Rep. SIR2005-5235, 37 pp.

Hornbeck, J. W., C. W. Martin, and C. Eagar, 1997: Summary of water yield experiments at Hubbard Brook Experimental Forest, New Hampshire. Can. J. For. Res., 27, 2043-2052, doi:10.1139/x97-173.

Huntington, T. G., 2005: Assessment of calcium status in Maine forests: Review and future projection. Can. J. For. Res., 35, 1109-1121, doi:10.1139/x05-034.

- 2006: Evidence for intensification of the global water cycle: Review and synthesis. J. Hydrol., 319, 83-95, doi:10.1016/ j.jhydrol.2005.07.003.

_ 2010: Climate warming-induced intensification of the hydrologic cycle: A assessment of the published record and the potential impacts on agriculture. Adv. Agron., 109, 1-53, doi:10.1016/B978-0-12-385040-9.00001-3.

Hurrell, J., 1995: Decadal trends in the North Atlantic Oscillation: Regional temperatures and precipitation. Science, 269, 676679, doi:10.1126/science.269.5224.676.

Irland, L. C., 1998: Maine's forest area, 1600-1995: Review of available estimates. Misc. Publ. 736, Maine Agricultural Forest Experimentation Station, University of Maine, $12 \mathrm{pp}$.

Jeon, S. B., P. Olofsson, and C. E. Woodcock, 2014: Land use change in New England: A reversal of the forest transition. J. Land Use Sci., 9, 105-130, doi:10.1080/1747423X.2012.754962.

Johnson, A. I., 1967: Specific yield-Compilation of specific yields for various materials. U.S. Geological Survey Water-Supply Paper 1662-D, 74 pp.

Jung, M., and Coauthors, 2010: Recent decline in the global land evapotranspiration trend due to limited moisture supply. $\mathrm{Na}$ ture, 467, 951-954, doi:10.1038/nature09396.

Karl, T. R., J. M. Melillo, and T. C. Peterson, Eds., 2009: Global Climate Change Impacts in the United States. Cambridge University Press, $188 \mathrm{pp}$.

Keim, B. D., A. Wilson, C. Wake, and T. G. Huntington, 2003: Are there spurious temperature trends in the United States Climate Division database? Geophys. Res. Lett., 30, 1404, doi:10.1029/2002GL016295.

—, M. R. Fischer, and A. M. Wilson, 2005: Are there spurious precipitation trends in the United States Climate Division database? Geophys. Res. Lett., 32, L04702, doi:10.1029/2004GL021985.

Kljun, N., T. A. Black, T. J. Griffis, A. G. Barr, D. Gaumont-Guay, K. Morgenstern, J. H. McCaughey, and Z. Nesic, 2006: Response of net ecosystem productivity of three boreal forest stands to drought. Ecosystems, 9, 1128-1144, doi:10.1007/ s10021-005-0082-x.

Kontis, A. L., A. D. Randall, and D. L. Mazzaferro, 2004: Regional hydrology and simulation of flow of stratified-drift aquifers in the glaciated northeastern United States. U.S. Geological Survey Professional Paper 1415-C, 156 pp.

Lauritsen, R. G., and J. C. Rogers, 2012: U.S. diurnal temperature range variability and regional causal mechanisms, 1901-2002. J. Climate, 25, 7216-7231, doi:10.1175/JCLI-D-11-00429.1.

McCabe, G. J., and D. M. Wolock, 2002: A step increase in streamflow in the conterminous United States. Geophys. Res. Lett., 29, 2185, doi:10.1029/2002GL015999.

$\ldots$, and _ 2011a: Century-scale variability in global annual runoff examined using a water balance model. Int. J. Climatol., 31, 1739-1748, doi:10.1002/joc.2198.

$\longrightarrow$, and $-2011 \mathrm{~b}$ : Independent effects of temperature and precipitation on modeled runoff in the conterminous United States. Water Resour. Res., 47, W11522, doi:10.1029/ 2011WR010630.

McVicar, T. R., and Coauthors, 2012: Global review and synthesis of trends in observed terrestrial near-surface wind speeds: Implications for evaporation. J. Hydrol., 416-417, 182-205, doi:10.1016/j.jhydrol.2011.10.024.

Milly, P. C. D., and K. A. Dunne, 2001: Trends in evaporation and surface cooling in the Mississippi River basin. Geophys. Res. Lett., 28, 1219-1222, doi:10.1029/2000GL012321.

Morin, X., M. J. Lechowicz, C. Augspurger, J. O'Keefe, D. Viner, and I. Chuine, 2009: Leaf phenology in 22 North American tree species during the 21st century. Global Change Biol., 15, 961-975, doi:10.1111/j.1365-2486.2008.01735.x.

Peel, M. C., B. L. Finlayson, and T. A. McMahon, 2007: Updated world map of the Köppen-Geiger climate classification. Hydrol. Earth Syst. Sci., 11, 1633-1644, doi:10.5194/ hess-11-1633-2007.

Qian, T., A. Dai, and K. E. Trenberth, 2007: Hydroclimatic trends in the Mississippi River Basin from 1948 to 2004. J. Climate, 20, 4599-4614, doi:10.1175/JCLI4262.1.

Ramanathan, V., P. J. Crutzen, J. T. Kiehl, and D. Rosenfeld, 2001: Aerosols, climate, and the hydrologic cycle. Science, 294, 2119-2124, doi:10.1126/science.1064034.

Randall, A. D., and A. J. Cohen, 1998: Mean annual runoff, precipitation, and evapotranspiration in the glaciated northeastern United States, 1951-1980. U.S. Geological Survey Open-File Rep. 96-395. [Available online at http://ny.water.usgs.gov/pubs/ of/of96395/OF96-395.plate2.pdf.]

Rawlins, M. A., and Coauthors, 2010: Analysis of the Arctic system for freshwater cycle intensification: Observations and expectations. J. Climate, 23, 5715-5737, doi:10.1175/ 2010JCLI3421.1.

Salmi, T., A. Määttä, P. Anttila, T. Ruoho-Airola, and T. Amnell, 2002: Detecting trends of annual values of atmospheric pollutants by the Mann-Kendall test and Sen's slope estimates. Publication on Air Quality 31, Finnish Meteorological Institute, $35 \mathrm{pp}$.

Sanford, W. E., and D. L. Selnick, 2013: Estimation of evapotranspiration across the conterminous United States using a regression with climate and land-cover data. J. Amer. Water Resour. Assoc., 49, 217-230, doi:10.1111/jawr.12010.

Sankarasubramanian, A., and R. M. Vogel, 2003: Hydroclimatology of the continental United States. Geophys. Res. Lett., 30, 1363, doi:10.1029/2002GL015937.

Scanlon, B. R., R. W. Healy, and P. G. Cook, 2002: Choosing appropriate techniques for quantifying groundwater recharge. Hydrogeol. J., 10, 18-39, doi:10.1007/s10040-001-0176-2.

Schneider, W. J., and G. R. Ayer, 1961: Effect of reforestation on streamflow in central New York. U.S. Geological 
Survey Water-Supply Paper 1602, U.S. Govt. Printing Office, $61 \mathrm{pp}$.

Schwartz, M. D., R. Ahas, and A. Aasa, 2006: Onset of spring starting earlier across the Northern Hemisphere. Global Change Biol., 12, 343-351, doi:10.1111/j.1365-2486.2005.01097.x.

Seager, R., M. Ting, C. Li, N. Naik, B. Cook, J. Nakamura, and H. Liu, 2012: Projections of declining surface-water availability for the southwestern United States. Nat. Climate Change, 3, 482-486, doi:10.1038/nclimate1787.

Senay, G. B., S. Leake, P. L. Nagler, G. Artan, J. Dickinson, J. T. Cordova, and E. P. Glenn, 2011: Estimating basin scale evapotranspiration (ET) by water balance and remote sensing methods. Hydrol. Processes, 25, 4037-4049, doi:10.1002/ hyp.8379.

Sheffield, J., E. D. Wood, and F. Munoz-Arriola, 2010: Long-term regional estimates of evapotranspiration for Mexico based on downscaled ISCCP data. J. Hydrometeor., 11, 253-275, doi:10.1175/2009JHM1176.1.

Stewart, G. J., J. M. Caldwell, A. R. Cloutier, and L. E. Flight, 2006: Water resources data: Maine water year 2005. USGS, Rep. WDR-ME-05-1, 277 pp. [Available online at http://pubs.usgs. gov/wdr/2005/wdr-me-05-1/.]

Sun, G. E., S. B. McLaughlin, J. H. Porter, J. Uddling, P. J. Mulholland, M. B. Adams, and N. Pederson, 2012: Interactive influences of ozone and climate on streamflow of forested watersheds. Global Change Biol., 18, 3395-3409.

Syed, T. H., J. S. Famiglietti, D. P. Chambers, J. K. Willis, and K. Hilburn, 2010: Satellite-based global-ocean mass balance estimates of interannual variability and emerging trends in continental freshwater discharge. Proc. Natl. Acad. Sci. USA, 107, 17916-17921, doi:10.1073/pnas.1003292107.

Tebaldi, C., K. Hayhoe, J. M. Arblaster, and G. A. Meehl, 2006: Going to the extremes: An intercomparison of model-simulated historical and future changes in extreme events. Climatic Change, 79, 185-211, doi:10.1007/s10584-006-9051-4.

Teuling, A. J., and Coauthors, 2009: A regional perspective on trends in continental evaporation. Geophys. Res. Lett., 36, L02404, doi:10.1029/2008GL036584.

Toppan, F. W., 1935: The physiography of Maine. J. Geol., 43, 76-87, doi:10.1086/624271.

Trenberth, K. E., 1999: Conceptual framework for changes of extremes of the hydrological cycle with climate change. Climatic Change, 42, 327-339, doi:10.1023/A:1005488920935.

_ 2011: Changes in precipitation with climate change. Climate Res., 47, 123-138, doi:10.3354/cr00953.

— , and D. J. Shea, 2005: Relationships between precipitation and surface temperature. Geophys. Res. Lett., 32, L14703, doi:10.1029/2005GL022760.

Trombulak, S. C., and R. Wolfson, 2004: Twentieth-century climate change in New England and New York, USA. Geophys. Res. Lett., 31, L19202, doi:10.1029/2004GL020574.
Vinukollu, R. K., E. F. Wood, C. R. Ferguson, and J. B. Fisher, 2011: Global estimates of evapotranspiration for climate studies using multi-sensor remote sensing data: Evaluation of three process-based approaches. Remote Sens. Environ., 115, 801-823, doi:10.1016/j.rse.2010.11.006.

Walter, M. T., D. S. Wilks, J.-Y. Parlange, and R. L. Schneider, 2004: Increasing evapotranspiration from the conterminous United States. J. Hydrometeor., 5, 405-408, doi:10.1175/ 1525-7541(2004)005<0405:IEFTCU>2.0.CO;2.

Wang, K., R. E. Dickinson, M. Wild, and S. Liang, 2010: Evidence for decadal variation in global terrestrial evapotranspiration between 1982 and 2002: 2. Results. J. Geophys. Res., 115, D20113, doi:10.1029/2010JD013847.

Weider, K., and D. F. Boutt, 2010: Heterogeneous water table response to climate revealed by 60 years of ground water data. Geophys. Res. Lett., 37, L24405, doi:10.1029/2010GL045561.

Wentz, F. J., L. Ricciardulli, K. Hilburn, and C. Mears, 2007: How much more rain will global warming bring? Science, 317, 233235, doi:10.1126/science. 1140746.

White, M. A., S. W. Running, and P. E. Thornton, 1999: The impact of growing-season length variability on carbon assimilation and evapotranspiration over 88 years in the eastern US deciduous forest. Int. J. Biometeor., 42, 139-145, doi:10.1007/ s004840050097.

Wilcox, L. J., E. J. Highwood, and N. J. Dunstone, 2013: The influence of anthropogenic aerosol on multi-decadal variations of historical global climate. Environ. Res. Lett., 8, 024033, doi:10.1088/1748-9326/8/2/024033.

Wild, M., 2009: Global dimming and brightening: A review. J. Geophys. Res., 114, D00D16, doi:10.1029/2008JD011470.

Willett, K. M., P. D. Jones, N. P. Gillett, and P. Thorne, 2008: Recent changes in surface humidity: Development of the HadCRUH dataset. J. Climate, 21, 5364-5383, doi:10.1175/ 2008JCLI2274.1.

Williams, C. N., Jr., M. J. Menne, R. S. Vose, and D. R. Easterling, 2005: United States historical climatology network monthly temperature and precipitation Data. Carbon Dioxide Information Analysis Center, ORNL/CDIAC-118, NDP-019. [Available online at http://cdiac.ornl.gov/epubs/ndp/ushcn/ usa_monthly.html.]

Wolfe, D. W., M. D. Schwartz, A. N. Lakso, Y. Otsuki, R. M. Pool, and N. J. Shaulis, 2005: Climate change and shifts in spring phenology of three horticultural woody perennials in northeastern USA. Int. J. Biometeor., 49, 303-309, doi:10.1007/ s00484-004-0248-9.

Wu, P., N. Christidis, and P. Stott, 2013: Anthropogenic impact on Earth's hydrological cycle. Nat. Climate Change, 3, 807-810, doi:10.1038/nclimate1932. 